\title{
Assessing the Potential Impact of the Marikana InCident on South African Mining Companies: An EVEnT MeThOd STUdY
}

\author{
Nicholas Hill and Warren Maroun \\ School of Accountancy, University of the Witwatersrand \\ Accepted: July 15
}

\begin{abstract}
This study examines the potential impact of industrial unrest and the outbreak of violence at Marikana on 16 August 2012 on the share prices of mining companies listed on the Johannesburg Stock Exchange (JSE) using an event methodology. Contrary to expectations, the Marikana incident does not appear to have had a widespread and prolonged effect on the South African mining sector. This may be the result of the strike action already having been discounted into the price of mining shares, implying that the market was only reacting to the unusually violent (but short-lived) protest. Alternately, the results could be indicative of investor confidence in the corporate social responsibility initiatives of the South African mining industry as a whole.

This paper is the first to examine the potential impact of the Marikana incident on the share prices of mining companies listed on the JSE. It should be of interest to both academics and practitioners wanting to understand how share prices react to exogenous events. It is also relevant for corporate-governance researchers concerned with the relevance of social and governance practices in a South African setting. This research is faced with the limitations associated with most statistical research: that causality cannot be ascribed to tested relationships. Notwithstanding these limitations, it is argued that these findings are important, given the significant coverage of the Marikana incident and the ongoing debate on the need for corporate social responsibility.
\end{abstract}

Key words: corporate social responsibility, corporate governance, event method, Marikana, South Africa

JEL: G14, M48

\section{$1 \quad$ Introduction}

On 16 August 2012, police units deployed in Marikana to manage an increasingly violent wildcat strike by mineworkers at Lonmin plc's (Lonmin) operations in Rustenburg, South Africa, opened fire, killing 34 and wounding an additional 78 people (Nkosi, 2012). In addition to the social and political implications (Evans, 2013; Marikana Commission of Inquiry, 2013; Van Graan, 2013), the incident had a material financial impact for Lonmin, which reported significant production stoppages and a material decline in share price (Reuters, 2012c), coupled with the risk of additional losses due to adverse reputational consequences (see, for example, the comments of Frankel, 2012). The ramifications of the Marikana incident for the South African platinum-mining industry as a whole are, however, less clear.

As such, the purpose of this research is to examine the relationship between the Marikana incident and the potential impact on the value of platinum-mining stocks listed on the JSE by identifying and measuring abnormal returns over a defined event period, using event methodology ${ }^{1}$. There are similar studies which have examined the effect of unusual events on share prices (for examples, see Hamilton, 1995; Chen \& Siems, 2004; Capelle-Blancard \& Laguna, 2010). To the best of our knowledge, few studies have, however, examined the possible impact of labour unrest on equity returns. Furthermore, despite the significant coverage in both the local and international press of the events unfolding at Marikana (Mabuse, 2012; Nkosi, 2012), there has been no formal academic work on their financial ramifications. Consequently, this research makes an important contribution to the corporate-governance literature by providing 
initial evidence on the possible share price impact of this widely publicised example of wildcat strike action in the South African platinum-mining sector.

In addition to stakeholders concerned with the possible implications of Marikana for Lonmin's share price, these findings should also be of interest to a broader corporate-governance community. "Marikana" has become infamous as possibly the most violent demonstration in postapartheid South Africa (Bond \& Mottiar, 2013), thereby pointing to political strife, growing social and economic inequality and, possibly, the beginning of the decline of South Africa's famous mining industry (Cawadas \& Mitchell, 2012; Evans, 2013; Marikana Commission of Inquiry, 2013; Van Graan, 2013). The labour unrest may also be indicative of poor corporate social responsibility (CSR) practices on the part of the country's mining houses (cf. Frankel, 2012). Given the growing body of research which points to a link between CSR and financial return (Kumar, Lamb \& Wokutch, 2002; Lamb, Kumar \& Wokutch, 2005; De Klerk \& De Villiers, 2012), the shooting of mineworkers on 16 August 2012 may have led to a crisis of confidence for the mining fraternity (cf. Patten, 1992; Patten, 2002), investor dissatisfaction and a decline in share prices across the JSE's mining sector. On the other hand, if the initial effects of Marikana on share prices were limited, this would suggest ${ }^{2}$ that, in general, effective CSR strategies by South African mining companies played an important role in limiting the financial impact of the strike action. As such, exploring the correlation between share prices and the Marikana incident makes an important contribution to the body of literature dealing with the relevance of sound corporate social behaviour, while adding to the limited research on how South Africa's capital market reacts to significant labour-related issues.

At this point, it must be stressed that the aim of this paper is not to assign blame or offer insights into the causes of the Marikana incident. The circumstances leading up to the demonstrations were very complex (cf. Marikana Commission of Inquiry, 2013; Lonmin plc, 2012). Labour relations between Lonmin and its employees were only a part of the events taking place on 16 August 2012 (Evans, 2013; Marikana Commission of Inquiry, 2013; Van Graan, 2013). There were a host of complex social, political and economic forces which were also at work (cf. Lonmin plc, 2012; Marikana Commission of Inquiry, 2013). Examining each of these contributing variables is beyond the scope of this research. In addition, the study is restricted to considering the potential financial impact of the Marikana incident, defined in terms of the abnormal and cumulative abnormal returns on share prices. Related to this, the time period under review is very short to avoid the impact of confounding events, with the result that the research cannot draw conclusions concerning the long-term implications of Marikana for the local mining industry.

The remainder of this paper is organised as follows: Section 2 provides a theoretical framework, discusses the application of event methodology and summarises the developments at Marikana, culminating in the event under review (the Marikana incident). Section 3 explains in more detail the use of the event method for the purpose of this study. Section 4 presents results and Section 5 analyses the results and discusses possible implications. Section 6 contains the conclusion and identifies areas for future research.

\section{Literature and background}

The "frictionless" system predicted by the efficient-market hypothesis (EMH) may only be theoretical, but the characteristics of efficient markets have been found, at least to some extent, "in real world markets" (Fama, 1965; Malkiel \& Fama, 1970:387-388). Consequently, although there have been criticisms of the simplifying assumptions of the EMH (see, for example, Basu, 1977; Clarke, Jandik \& Mandelker, 2001), the theory is generally accepted as providing a reasonable basis for describing changes in share prices (Malkiel, 2003). In particular, the ability of capital markets to respond efficiently to publicly available information has allowed for a plethora of research, using event methodology, on the market's reaction to the release of potentially pricesensitive information (Schwert, 1981). 


\subsection{Event-study methodology}

Studies using event methodology provide interesting accounts of how markets, which are at least semi-strong form efficient, react to specific events (Kothari \& Warner, 2006; Donnelly, 2008). Rosen (2006), for example, identifies how the announcement of a merger (a single event) can trigger a short-term movement in stock price based on investor sentiment. Other papers have considered the relationship between share prices and earnings announcements (Chambers \& Penman, 1984), new equity issues (Barclay \& Litzenberger, 1988), and disclosures of changes in bond prices by rating agencies (Hand, Holthausen \& Leftwich, 1992).

From a broader perspective, event method studies have also been successfully applied when exploring the possible impact on share prices of events beyond an organisation's control. Worrell and Davidson (1987), for example, examined the impact of chief executive officer (CEO) succession on the wealth of shareholders following the death of their predecessors. Dealing with the relevance of environmental issues, White (1996) examined the potential impact of the Exxon Valdes oil spill on stock prices, while Kalra, Henderson \& Raines (1993) considered the implications of the Chernobyl nuclear disaster on utility share prices. More recently, Hovav and D'Arcy (2003) successfully applied event methodology to highlight the possible implications of "denial of service" attack announcements on affected firms' stock prices. Likewise, Chen and Siems (2004) assessed the immediate impact which terrorist attacks had on the United States of America's (USA's) capital markets. Event methods have also been applied to examine the relevance of accounting information. Donnelly (2008), for instance, examined the behaviour of share prices of Irish companies at the time of the Wall Street Journal publishing criticisms of the accounting practices of a local pharmaceutical company.

Event methods have also been successfully applied in a South African setting. Although there may be some opportunities for exploiting market inefficiency, the conclusion is that the JSE is at least semi-strong form efficient (Glass \& Smit, 1995; Jefferis, Okeahalam \& Matome, 1999; Magnusson \& Wydick, 2002; Jefferis \& Smith, 2004). Consequently, several studies have been able to demonstrate how South African equity instruments react to market announcements such as management buyouts (Bhana, 2005), unbundling transactions (Bhana, 2006), and share repurchases (Bhana, 2007) using event methodology. The technique has also been successfully applied in examining the connection between CSR and share price returns.

\subsection{Corporate social responsibility, event methodologies and Marikana}

There is a large body of literature dealing with the relationship between CSR and the financial performance of organisations (cf. Griffin \& Mahon, 1997; Roman, Hayibor \& Agle, 1999; Ullmann, 1985; De Klerk and De Villiers, 2012). As pointed out by McWilliams and Siegel (1997) and by Wood and Jones (1995), a key challenge has been that of clearly demonstrating the mechanisms by which favourable or unfavourable corporate social behaviour translates into financial returns. This problem has often been addressed using event methodologies (or similar techniques) to match plausibly the relationship between specific actions or events and changes in share prices (Kumar et al., 2002). In particular, event methodology has been successfully employed to highlight the possible interconnection between boycotts against South African firms during apartheid (as an example of a social corporate action) and share price returns.

Meznar, Nigh and Kwok (1994), for example, report on the effect of announcements by American firms to disinvest in South Africa during the 1980s. This investment decision met the social expectations of certain stakeholder groups, thereby placing pressure on American business to boycott South African investments, but also resulted in a loss of value for shareholders due to forgone business opportunities (cf. Wright \& Ferris, 1997) ${ }^{3}$. This effect was more pronounced for earlier withdrawal announcements, in line with the variability of the perceived costs and benefits of boycotting South African investments during the 1980s (Meznar et al., 1994; Meznar, Nigh \& Kwok, 1998). Although the precise effect of withdrawal announcements on share values is difficult to determine (Meznar et al., 1998) - and is subject to some debate (McWilliams \& Siegel, 
1997; Teoh, Siew, Welch \& Wazzan, 1999) - the general consensus is that there was at least a negative correlation between the announcement of a decision to divest from South Africa and equity returns (Wright \& Ferris, 1997; Meznar et al., 1998).

In turn, this has important implications for the traditional position that, in the absence of material agency problems, managers ought to operate in the best interest of shareholders (Berle \& Means, 1932; Jensen \& Meckling, 1976; Freeman, 1984). Faced with mounting public criticism on account of their business relationships with South African entities, many American organisations engaged in a pluralistic investment decision-making process which was mindful of the interests of multiple stakeholder groups. This culminated in disinvestment from South Africa, even if this resulted in an initial loss of value for shareholders (Meznar et al., 1994).

In the long run, however, firms which continued to remain invested in South Africa were increasingly penalised by a socio-ethical investment movement taking hold as social activism during the 1980s and early 1990s gained momentum (Kumar et al., 2002). In other words, the initial costs of withdrawing from South Africa (Meznar et al., 1994) were eventually exceeded by the negative implications (including the detrimental effect on share prices) of remaining invested in the country (Meznar et al., 1998; Kumar et al., 2002). There is also evidence to suggest that withdrawing from South Africa resulted in a type of social legitimacy reserve which contributed to the share prices of companies (which committed to social activism against apartheid) outperforming peers in the days following the end of sanctions against South Africa in 1993 (Lamb et al., 2005). In this way, "social/ethical investing can be a powerful force in the stock market based strictly on the investment decisions made by social/ethical investors themselves" and can "be an even stronger force by influencing the decisions of other investors in general" (Kumar et al., 2002; Lamb et al., 2005:12).

This logic remains valid in post-apartheid South Africa. The evolution of responsible investment has been influenced significantly by the country's codes on corporate governance, which have engendered a stakeholder-centric model for corporate reporting (Institute of Directors in Southern Africa [IOD], 2009; Solomon, 2010). Complementing this is the country's drive to promote integrated thinking and reporting by companies which recognises the need to balance financial performance with a broad range of sustainability indicators (Integrated Reporting Committee of South Africa [IRCSA], 2011; JSE 2013). This has gone hand in hand with: the commitment of certain South African institutions to the Principles of Responsible Investment (backed by the United Nations) (IOD, 2011); the publication of the Code for Responsible Investment in South Africa to drive the integration of sustainability issues in strategic investment decision making (IOD, 2011; Solomon \& Maroun, 2014; Atkins and Maroun, 2015); and the development of the JSE's Responsible Investment Index to identify those listed companies with good social and environmental credentials (Ernst \& Young, 2012; Solomon \& Maroun, 2012; Atkin and Maroun, 2014).

In this context, there is an emerging body of academic work which has concluded that CSR practices - including corporate responsibility reporting (CRR) - are value-relevant in capital markets (De Klerk \& De Villiers, 2012; Flammer, 2013; Chen, Wang \& Wang, 2014). Carroll and Shabana (2010), for example, argue that CRR has a positive effect on the financial performance of an organisation, benefitting shareholders (and other stakeholders) mainly in the form of increased competitive advantage, gains from risk reduction, and reputational benefits for the reporting entity (cf. Solomon, 2010; King, 2012). Analogously, Gregory, Tharyan and Whittaker (2013) find that firms with sound governance practices generally have better longer-term growth prospects, coupled with slightly lower costs of equity. De Klerk and De Villiers (2012) reached a comparable conclusion in a South African context, finding that firms which actively report on CSR issues tend to enjoy higher share prices. These findings are consistent with evidence suggesting that South African companies complying with the Global Reporting Initiative (GRI) reporting guidelines enjoyed superior financial performance - measured in terms of earnings per share, headline earnings per share, return on assets, and returns on equity - than those organisations which did not comply with the guidelines (Buys, Bosman \& Van Rooyen, 2009). Although some researchers 
have disputed the positive correlation between CRR and share prices (cf. Hassel, Nilsson \& Nyquist, 2005; Jones, Frost, Loftus \& Van Der Laan, 2007), the active management of and reporting on environmental, social and governance (ESG) issues is generally regarded as an imperative for investment analysts dealing with South African companies (cf. De Klerk and De Villiers, 2012; King, 2012; Solomon \& Maroun, 2014).

Ultimately, the growing social pressure to incorporate ESG metrics into investment decision making reinforces the business case for socially responsible investment practices (cf. Lamb et al., 2005; IOD, 2011; Solomon \& Maroun, 2014) and implies that there should be a positive relationship between the sound CSR practices of an organisation and its share price returns (Meznar et al., 1994; Meznar et al., 1998; Kumar et al., 2002; Lamb et al., 2005; De Klerk \& De Villiers, 2012) ${ }^{4}$. In other words, with an increased emphasis on the importance of non-financial metrics, an event which is perceived to impact negatively the CSR practices of an organisation should lead to negative investor sentiment and a decline in share prices (cf. Meznar et al., 1994; Meznar et al., 1998; Patten, 2002; De Klerk \& De Villiers, 2012). The same should apply to the events leading up to the shooting of mineworkers on 16 August 2012.

Given the semi-strong form efficiency of the JSE (Glass \& Smit, 1995; Choudhry, 1999; Jefferis et al., 1999; Magnusson \& Wydick, 2002), this event had a direct effect on Lonmin's operations (Reuters, 2012c) and would have been taken into account by market participants when pricing the company's shares (cf. Malkiel \& Fama, 1970; Brealey, Myers \& Allen, 2008). The Marikana incident may also have been indicative of labour relation problems in the platinum and South African mining sector as a whole (cf. Frankel, 2012; Lonmin, 2012), leading to a withdrawal from the sector in response to a perception of poor CSR practices. Before exploring the potential impact of the Marikana incident on the share prices of South African platinummining companies, a brief background of the events taking place at Marikana is provided.

\subsection{The Marikana incident}

The Marikana incident is considered a significant event in South African history, with parallels drawn between the Marikana shootings and the Sharpeville and Soweto uprisings of 1960 and 1976, respectively (Sorensen, 2012). The event attracted significant attention from local and international media due to the number of casualties, as well as the historical sensitivity associated with the South African Police Service's (SAPS's) use of force (Marinovich, 2012). Marikana also evoked a response from the investor community, with many questioning whether the industrial unrest was indicative of widespread problems with labour relations and the beginning of the end of the South African mining industry (Cawadas \& Mitchell, 2012).

The Marikana incident was the climax of a year of strike action in the South African mining industry. which witnessed the highest number of protests per month since the end of apartheid (McClenaghan, 2012). Unrest in the mining sector was first started by rock drill operators (RDOs) at the Impala Platinum mine in January 2012 (Chinguno, 2013). The mandate from the RDOs was a wage increase of 200 per cent because of a decision made by management to award mine blasters an 18 per cent increase in retention allowances. The RDOs wanted to prevent the involvement of their union - the National Union of Mineworkers (NUM) - which had taken the position that workers' demands were unattainable. As such, they (the RDOs) rejected any approach for representation by NUM and opted instead to form an independent committee to present their demands to management. This rejection of NUM allowed the Association of Mining and Construction Union (AMCU) to emerge as a competitor in the industrial relations arena (Onslow, 2012). Trade union rivalry was, therefore, inseparable from the economic demands of the striking mineworkers.

The strike gained notoriety because of acts of violence and levels of worker activism (Onslow, 2012). Additionally, it saw the demise of the old collective-bargaining process, which the workers perceived to be outdated and unable to meet their aspirations (Cawadas \& Mitchell, 2012). Management ultimately conceded to worker demands and offered a 22 per cent increase in the 
gross package (Bond \& Mottiar, 2013), which, inadvertently, made wildcat strike action more attractive for workers and set a precedent for future wage dispute strategies (Chinguno, 2013).

Born out of the success of the independent bargaining wage negotiations at Impala Mines, the workers at Lonmin saw an opportunity for their own wage negotiations. This thinking was based on disillusionment with formal union representation (Cawadas \& Mitchell, 2012; McClenaghan, 2012). Workers felt that wages were failing to meet their living costs, since stop-order loan repayment systems (microcredit lending facilities) (Bateman, 2012) were significantly reducing their take-home pay (Bond \& Mottiar, 2013). Inspired by the previous strike action by mineworkers at the Impala Mine, workers at Lonmin (in Marikana) embarked on a wildcat strike on 10 August 2012 (Marinovich, 2012).

Workers rejected attempts by NUM to mediate the conflict and followed the model of the Lonmin strikers, forming independent committees to champion their cause (Chinguno, 2013). Lonmin management was aware of the failure of Impala management to engage with the workers via the old collective-bargaining approach and, instead, elected to respond to the workers outside of the traditional negotiation framework. NUM disagreed with the process, something which angered workers, who felt that the union was interfering. Clashes ensued between protesting workers and union officials, the first of which took place on 11 August 2012. Marching strikers were met with gunfire from NUM members, resulting in the death of two workers (Bond \& Mottiar, 2013). Continuing unrest resulted in an increase in the police presence in the area. On 16 August 2012, the police units were deployed to move the striking miners from a hill where they had been gathering for a number of days. The police positioned barbed-wire fencing and fired tear gas in an attempt to disperse the striking workers. As the workers descended from their position, the SAPS opened fire on the miners, killing 34 and wounding an additional 78 (Nkosi, 2012). The motives of the SAPS officers were unclear, but it has been suggested that one of the workers was carrying a pistol and fired the first shots, causing the SAPS to retaliate (Bond \& Mottiar, 2013).

In the aftermath of the incident, the Marikana Commission was established to investigate (Evans, 2013; Smith, 2013), but - at the time of analysing the data - was yet to conclude its work (Bond \& Mottiar, 2013). What the Marikana incident has confirmed is that mining companies need to pay attention to CSR initiatives and, in particular, strategies for managing labour relations (cf. Frankel, 2012; Lonmin, 2012). In the aftermath of the strike action, Lonmin announced that industrial unrest had resulted in an immediate loss of 15000 ounces of platinum production (Reuters, 2012c). Marikana has, as discussed above, also contributed to the growing status of wildcat strikes (McClenaghan, 2012), something which may have an impact on investors' assessment of operational risks in the platinum-mining industry. As the incident could be pointing to broader CSR challenges, it is also possible that Marikana resulted in a general withdrawal of investment and a short-term reduction in share prices across the JSE's platinum-mining sector.

3 Method

\subsection{Event methodology}

Event-study methodology is a forward-looking, generally accepted approach which identifies abnormal returns associated with a particular event (Bowman, 1983; Kothari \& Warner, 2006). Economic models - such as those making use of the Capital Asset Pricing Model (Sharpe, 1964; Lintner, 1965) or Arbitrage Pricing Theory (Ross, 1976) - are not widely applied, as the benefit of enhanced accuracy seldom justifies the costs of using more complex statistical techniques (Brown \& Warner, 1985; MacKinlay, 1997). More common are the Constant Mean Return and Market Model - which do not yield significantly different results from econometric models (Brown \& Warner, 1985; Chen \& Siems, 2004; Corrado, 2011).

MacKinlay (1997) recommends the use of the Market Model, as it removes abnormalities in the return, associated with market variations, and incorporates a measure of systematic risk (Fama, Fisher, Jensen \& Roll, 1969; Corrado, 2011). The model has frequently been applied by more 
recent event studies providing a comparative base of use (Chen \& Siems, 2004; Donnelly, 2008). In terms of this model, the expected return on a particular share at a specified time, using an equally weighted index (Brown \& Warner, 1985), is given by Equation 1:

Equation 1

$$
R_{i t}=a+b \times R M_{t}+e_{t}
$$

$R_{i t}$ and $R M_{i t}$ are the returns on a specified share and the return of the overall market at time $(t)$. This method removes the effect of the economy-wide (market) returns on the stock (i), while dissecting just the return related to firm-specific information. The firm-specific return isolated from that of the market is $e_{t}$. The Market Model parameters of a (the excess of return, relative to a specific benchmark index) and $b$ (the measure of correlation in change of a specified share in relation to a designated index) are determined by ordinary least squares regression of firm-returns $R_{i t}$ and market $R M_{i t}$ over a defined estimation window (Brown \& Warner, 1985; Kothari \& Warner, 2006; Corrado, 2011). It is assumed that these coefficients will remain constant during the event and estimation windows (Binder, 1998).

The abnormal return $\left(A R_{i t} S\right)$ determined as the difference between the predicted return and the actual return (Brown \& Warner, 1980). The cumulative abnormal return (CAR) is then computed by aggregating the difference between the actual and expected returns over the event window and, in theory, provides a measure of the sustained impact of the Marikana incident on the returns of platinum-mining companies (cf. Harvey \& Sticht, 2014) under the assumption that the JSE is semi-strong form efficient. The cross-sectional mean abnormal return for $N$ securities over a multiperiod interval $\left(t_{1}, t_{2}\right)$ is determined using Equation 2 (Fama et al., 1969; Kothari \& Warner, 2006):

$$
\begin{aligned}
& \text { Equation } 2 \\
& \qquad \operatorname{CAR}_{\left(t_{1}, t_{2}\right)}=\sum_{t=t_{1}}^{t_{2}} A R_{t}
\end{aligned}
$$

The main hypothesis, in the null form, is that the Marikana incident should have had no impact on abnormal returns, given that the market was at least semi-strong form efficient (Bhana, 2007). This is consistent with the fact that wage negotiations between South African mining houses and labour usually take place during the months of June to August. The financial effects of the Marikana strike action (which occurred during the traditional "strike season") would, therefore, have already been taken into account by market participants.

The first hypothesis is supplemented by two additional hypothesis tests dealing with the cumulative abnormal returns over three- and five-day periods (adapted from Chen \& Siems, 2004). These hypotheses are stated as follows:

(1) $H_{1}: A R_{t}=0$

(2) $H_{2}: \mathrm{C} A R_{t+2}=0$

$$
\begin{aligned}
& H_{A}: A R_{t} \neq 0 \\
& H_{A}: C A R_{t+2} \neq 0 \\
& H_{A}: C A R_{t+5} \neq 0
\end{aligned}
$$$$
\text { (3) } H_{3}: \mathrm{C} A R_{t+5}=0
$$

To determine the significance of event-date abnormal returns $\left(\mathrm{H}_{1}\right)$ and the cumulative abnormal returns three $\left(\mathrm{H}_{2}\right)$ and five days $\left(\mathrm{H}_{3}\right)$ after the event, the t-tests proposed by Patell (1976), Kothari and Warner (2006), and MacKinlay (1997) are used. The null hypotheses (that abnormal and cumulative abnormal returns on the event date have an expected value of zero during the event period) are rejected if the test statistics exceed a critical value below a 5 per cent level of significance (Kothari \& Warner, 2006; Capelle-Blancard \& Laguna, 2010). This threshold is widely accepted in event-study methodology literature as an appropriate level of confidence for accepting or rejecting the null hypothesis and minimising the possibility of a Type I error (rejecting a null hypothesis that is actually true) (Kothari \& Warner, 2006; Capelle-Blancard \& Laguna, 2010). The sign and rank test for event studies proposed by Corrado (1989) is used to 
supplement the parametric t-tests. The sign and rank test is regarded as more robust when there are deviations from normality, data outliers and date-variance increases (Donnelly, 2008; Kolari \& Pynnönen, 2010; Corrado, 2011) 5 and is important for confirming the initial results from the ttests. Nevertheless, it must be stressed that event methodology does not prove a causal relationship between an event and changes in share prices. While this is an inherent limitation of noneconometric techniques, the chosen Market Model is useful for highlighting trends in share prices over a defined event period to enable additional, albeit normative, analysis by researchers.

\subsection{Population, sample and data}

The expected, abnormal and cumulative abnormal returns were determined for all companies listed on the JSE's mining index during the period 1 January 2012 to 23 August 2012 (i.e. a period of five days' trading after the Marikana incident). Share prices and daily volume trades were obtained from the Bloomberg database for the observation period and were adjusted for the effects of share splits, rights issues and share consolidations.

A total of 54 companies were included in the analysis. The small sample size makes generalisation of the findings problematic and is an inherent limitation of the study given the limited number of mining companies listed on the $\mathrm{JSE}^{6}$. At this point, it should also be noted that the study does not concentrate on all companies listed on the JSE in order to avoid the risk of additional variables contributing to abnormal returns (if any). Instead, the research is focused on examining the possible connection between share prices of platinum-mining companies and Marikana due to the fact that the strike directly impacted the country's platinum producers (cf. Lonmin plc, 2012; Nkosi, 2012).

\subsection{Test period}

The test period is divided into two sections: the estimation window and the event window. The complete test period begins on 3 January 2012 (beginning of the 2012 trading year) and runs for 145 trading days (up until 31 July 2012). This period is consistent with that used by Chen and Siems (2004) and should provide a sufficiently long period for the determination of expected and abnormal earnings (Donnelly, 2008). It should, however, be stressed that the relatively short event period means that the long-term implications of the Marikana incident are not addressed and must be deferred for future research.

The event window begins on 16 August 2012 (the date of the Marikana incident), defined as $t_{0}$, and runs for a period of five days subsequent to the event $\left(t_{+5}\right)$ for a total window of six days (adapted from Chen \& Siems, 2004; Bhana, 2005; Bhana, 2006). This is consistent with the event window used in comparable studies (Chen \& Siems, 2004; Donnelly, 2008) and is in line with the recommendation that long time horizons be avoided to improve the reliability of the findings (Kothari \& Warner, 2006; Sprenger, Sandner, Tumasjan \& Welpe, 2014). Although a longer event window is preferred in order to address the problems posed by thin trading, this increases the risk of developments, other than those under review, impacting returns and obscuring results. To address thin trading, the researchers also ensured that none of the companies included in the test reported a zero share price movement during the event period (Donnelly, 2008).

\section{Results}

\subsection{Abnormal returns (ARs) and cumulative abnormal returns (CARs)}

Table 1 shows the ARs and CARs for each platinum-mining company listed on the JSE. The ARs are calculated on the date of the Marikana incident and the CARs are calculated at both two-day and five-day intervals post the event. Abnormal returns which are significant at the 10 per cent, 5 per cent or 1 per cent level (per the t-tests) are marked with an asterisk. 
Table 1

Platinum-mining sector

\begin{tabular}{|l|l|r|c|c|}
\hline \multicolumn{1}{|c|}{ Share code } & \multicolumn{1}{|c|}{ Company name } & \multicolumn{1}{c|}{ CARs 3-day } & CARs 6-day \\
\hline AMS & Anglo American Plat Ltd & $-1.008 \%$ & $-1.126 \%$ & $2.871 \%$ \\
\hline AQP & Aquarius Platinum Ltd & $0.973 \%$ & $6.242 \%$ & $19.932 \%{ }^{*}$ \\
\hline ATL & Atlatsa Resources Corp. & $-11.122 \%$ & $3.128 \%$ & $7.479 \%$ \\
\hline BAU & Bauba Platinum Ltd & $0.166 \%$ & $-16.279 \%$ & $1.657 \%$ \\
\hline EPS & Eastern Platinum Ltd & $-8.076 \%$ & $-6.534 \%$ & $3.981 \%$ \\
\hline IMP & Impala Platinum Holdings Ltd & $-1.642 \%$ & $1.351 \%$ & $2.462 \%$ \\
\hline JBL & Jubilee Platinum Plc & $0.198 \%$ & $2.336 \%$ & $-0.190 \%$ \\
\hline LON & Lonmin Plc & $-8.402 \% * * *$ & $--10.856 \% *$ & $-7.302 \%^{*}$ \\
\hline NHM & Northam Platinum Ltd & $-2.480 \%$ & $-1.703 \%$ & $6.324 \%$ \\
\hline PLL & Platfields Ltd & $-29.524 \%$ & $1.469 \%$ & $0.456 \%$ \\
\hline RBP & Royal Bafokeng Platinum Ltd & $-2.236 \% *$ & $-4.239 \% *$ & $-4.976 \%{ }^{*}$ \\
\hline WEZ & Wesizwe Platinum Ltd & $-2.997 \%$ & $0.186 \%$ & $12.166 \%$ \\
\hline
\end{tabular}

${ }^{*}$ Significant at a $90 \%$ confidence level; ${ }^{* *}$ Significant at a 95\% confidence level; ${ }^{* * *}$ Significant at a $99 \%$ confidence level

Table 1 shows that only Lonmin experienced a significant abnormal return on the date of the incident. The CARs three and six days after the event are only significant at the 10 per cent level. As the initial results in Table 1 suggested that the Marikana incident had a limited effect on the platinum mines, the researchers decided to confirm this by running the event-method tests described in Section 3 for all companies included in the JSE's mining sector (see Appendix A). Table 2 shows only those mining houses which experienced significant abnormal returns (ARs) on the event date or showed a significant three-day or six-day cumulative abnormal return ("CARs 3day" and "CARs 6-day") after the event. The t-test values are shown in brackets below the abnormal return results.

Table 2

Summary of significant results

\begin{tabular}{|c|c|c|c|c|}
\hline Company name & Mining sector & AR & CARs 3-day & CARs 6-day \\
\hline Wesizwe Platinum Ltd & Plat. & $\begin{array}{c}-2.997 \% \\
(-0.91)\end{array}$ & $\begin{array}{c}0.186 \% \\
(0.03)\end{array}$ & $\begin{array}{c}12.166 \% * \\
(1.50)\end{array}$ \\
\hline Pan African Resources Plc & Gold & $\begin{array}{c}2.466 \%^{*} \\
(1.82)\end{array}$ & $\begin{array}{c}-6.460 \% * \\
(-2.76)\end{array}$ & $\begin{array}{c}-2.619 \% \\
(-0.78)\end{array}$ \\
\hline Keaton Energy Holdings Ltd & Coal & $\begin{array}{c}-1.667 \% \\
(-0.62)\end{array}$ & $\begin{array}{c}-5.046 \% \\
(-1.09)\end{array}$ & $\begin{array}{c}-12.268 \% * \\
(-1.85)\end{array}$ \\
\hline Royal Bafokeng Platinum Ltd & Plat. & $\begin{array}{c}-2.236 \% * \\
(-1.71)\end{array}$ & $\begin{array}{c}-4.239 \%{ }^{*} \\
(-1.87)\end{array}$ & $\begin{array}{c}-4.976 \% * \\
(-1.54)\end{array}$ \\
\hline Coal Of Africa Ltd & Coal & $\begin{array}{c}-1.220 \% \\
(-0.44)\end{array}$ & $\begin{array}{c}-4.686 \% \\
(-0.97)\end{array}$ & $\begin{array}{c}-10.346 \% * \\
(-1.50)\end{array}$ \\
\hline Central Rand Gold Ltd & Gold & $\begin{array}{c}20.696 \% \%^{* *} \\
(2.27)\end{array}$ & $\begin{array}{c}29.555 \% * \\
(1.87)\end{array}$ & $\begin{array}{c}12.841 \% \\
(0.57)\end{array}$ \\
\hline Great Basin Gold Ltd & Gold & $\begin{array}{c}-20.171 \% \text { *** } \\
(-4.29)\end{array}$ & $\begin{array}{c}-19.151 \% * \\
(-2.35)\end{array}$ & $\begin{array}{c}-13.007 \% \\
(-1.12)\end{array}$ \\
\hline Aquarius Platinum Ltd & Plat. & $\begin{array}{c}0.973 \% \\
(0.27)\end{array}$ & $\begin{array}{c}6.242 \% \\
(1.00)\end{array}$ & $\begin{array}{c}19.932 \% * \\
(2.23)\end{array}$ \\
\hline Randgold \& Exploration Company Ltd & Gold & $\begin{array}{c}-0.260 \% \\
(-0.05)\end{array}$ & $\begin{array}{c}-24.230 \% * \\
(-2.67)\end{array}$ & $\begin{array}{c}-24.786 \% * \\
(-1.91)\end{array}$ \\
\hline Harmony Gold Mining Company Ltd & Gold & $\begin{array}{c}1.516 \% \\
(0.86)\end{array}$ & $\begin{array}{c}-10.177 \% * \\
(-3.32)\end{array}$ & $\begin{array}{c}-4.116 \% \\
(-0.94)\end{array}$ \\
\hline Northam Platinum Ltd & Plat. & $\begin{array}{c}-2.480 \% \\
(-1.64)\end{array}$ & $\begin{array}{c}-1.703 \% \\
(-0.65)\end{array}$ & $\begin{array}{c}6.324 \% * \\
(1.69)\end{array}$ \\
\hline Lonmin Plc & Plat. & $\begin{array}{c}-8.402 \%^{* * *} \\
(-5.74)\end{array}$ & $\begin{array}{c}-10.86 \% * \\
(-4.28)\end{array}$ & $\begin{array}{c}-7.302 \% * \\
(-2.01)\end{array}$ \\
\hline Petmin Ltd & Iron & $\begin{array}{c}-0.172 \% \\
(-0.09)\end{array}$ & $\begin{array}{c}-4.378 \% \\
(-1.35)\end{array}$ & $\begin{array}{c}-8.850 \% * \\
(-1.92)\end{array}$ \\
\hline
\end{tabular}

*Significant at a 90\% confidence level; ${ }^{* *}$ Significant at a $95 \%$ confidence level; ${ }^{* * *}$ Significant at a $99 \%$ confidence level 
As shown in Table 2, of the platinum-mining companies, only Lonmin experienced abnormal returns which were significant at the 1 per cent level. The only other mining company with significant abnormal returns at this level was Great Basin Gold Ltd (GBG) (discussed in detail in Section 5). These results were confirmed by non-parametric testing. The sign test statistic measures the significance of the signs of the population tested in terms of the event date (AR) and the event windows for two (CAR 3) and five days post the event (CAR 6) (Appendix B). The rank test was then applied across the entire population for the duration of the event window (CAR 6). The untabulated results were not significant when compared with the entire population of companies listed in the JSE mining sector.

Taken together, the information presented in Table 1 and Table 2 suggests that the Marikana incident had a limited impact on the South African mining industry. For robustness, the researchers expanded the test to consider all companies listed on the JSE. Comair Ltd (which was entering business rescue) was the only other company with a significant AR (at the 1 per cent level) ${ }^{7}$. In addition, Table 3 shows only five listed companies (out of 432 observations) with significant three- and six-day CARs using a 99 per cent confidence interval.

Table 3

Significant CARs: All companies

\begin{tabular}{|l|c|c|}
\hline \multicolumn{1}{|c|}{ Company } & $\begin{array}{c}\text { CARs 3-day } \\
\text { test statistic }\end{array}$ & $\begin{array}{c}\text { CARs 6-day } \\
\text { test statistic }\end{array}$ \\
\hline African \& Overseas Ent-N Shs & -0.15144 & 13.67021 \\
\hline Buildmax Ltd & 0.074174 & -5.02571 \\
\hline Silverbridge Holdings Ltd & -0.07571 & -9.86149 \\
\hline Ah-Vest Ltd & 8.257911 & 6.854913 \\
\hline African Eagle Resources Plc & -6.63171 & -4.59455 \\
\hline
\end{tabular}

As a final check on the limited impact of the Marikana incident, the researchers tested the net equity sales to or from foreign investors (denominated in USD) for significance. The untabulated results show significant cash outflows (at the 1 per cent level) only on the event date. Similarly, while there was a net sale of South African bonds by foreign investors on the date of the Marikana incident (untabulated), significant cash flows were only reported the day after the incident (and then only at the 5 per cent level).

Despite these robustness tests, it is important to note a key limitation of the event method discussed above before proceeding with an analysis of the results. In addition to using short time periods to avoid incorporating the effect of additional information on share prices (Section 3), event studies typically include multiple events of the same type. This addresses the risk of unrelated developments resulting in a significant statistical relationship under the assumption that confounding news emerges randomly (cf. Chen \& Siemens, 2004; Bhana, 2007). In this case, there are no suitable comparable events and the discussion below must be read in the light of this inherent limitation.

\section{Discussion}

The event methodology does not test for a causal relationship between a specific event and the share price. Nevertheless, the significance of the t-test statistics - coupled with the fact that Lonmin employees were directly involved in the Marikana incident - makes it reasonable to conclude that the event had a significant negative impact on the company's share price. Abnormal returns on the event date (16 August 2012) are significant at the 1 per cent level. The abnormal return is strongly negative, with an 8.42 per cent abnormal return observed for Lonmin on the day of the Marikana incident. Over a single trading day, from 15 to 16 August 2012, the share price declined 7.34 per cent from R90.33 to R83.70 (BFA McGregor database). This went hand in hand with a high volume of trade volatility where the event date volume traded was 253 per cent of the average volume of the trades over the estimation window (Appendix C). 
What is less expected is the absence of significant results for the remaining platinum and other mining companies listed on the JSE. A notable exception is GBG, which was the only other company to report abnormal returns at the 1 per cent level (Table 2). This company also reported the highest volume of share trades at 734 per cent (Appendix C). A review of the financial press by the researchers highlighted no direct links to the Marikana incident but did reveal that the company was in the process of applying for business rescue (Reuters, 2012a). Although the event method was not expanded to test for the statistical relevance of the announcement of goingconcern challenges, it would be reasonable to conclude that looming business rescue was a likely determinant of the share price, rather than the Marikana incident which, as per Appendix A, did not appear to have a widespread significant impact at the 1 per cent level. This was confirmed by a rank test (Appendix C) which identified the abnormal returns of Lonmin and GBG as the most significant at the 1 per cent level.

Positive abnormal returns, significant at a 95 per cent confidence level, were also experienced by Central Rand Gold Ltd. These were not expected, given the adverse nature of the Marikana incident (Table 2). A review in the financial press suggested that this was the result of the release of favourable analyst reports (Stanley, 2012). As with GBG, this company was not directly involved in the Marikana incident and is not a platinum producer. Together with the fact that there were no other mining companies which reported significant abnormal returns at the 1 per cent level (Appendix A), this finding implies a limited reaction to Marikana by investors.

Although some companies experience significant abnormal returns at the 10 per cent level, this was regarded as insufficient for the purpose of concluding that the Marikana incident was meaningfully correlated with the returns quoted by these companies (cf. Kothari \& Warner, 2006; Capelle-Blancard \& Laguna, 2010). This is consistent with the findings from the t-tests on the CARs for the three- and six-day periods. Results were only significant at the 10 per cent level (Table 3) and were also regarded as inadequate for drawing conclusions regarding the correlation between the Marikana incident and the abnormality of reported cumulative returns (cf. Kothari \& Warner, 2006; Capelle-Blancard \& Laguna, 2010).

Therefore, it appears that the Marikana incident had little effect on the returns of the South African mining sector as a whole. This was corroborated by a sign and rank test (Appendix B) applied to the entire population of mining companies on the event date. The relevant test statistics are not significant at the 1 per cent or 5 per cent level, implying that the mining sector did not treat this event as significant. This is consistent with the fact that - as discussed in Section 4 - there was no significant net sale of South African equities and bonds by foreign investors post 16 August 2012. Once again, only Lonmin reported a significant change in returns which appeared to be related to the Marikana incident, albeit that the effect was limited to a short time period (the CARs are only significant at a 10 per cent level).

A possible explanation for this is the containment measures which the company implemented in order to mitigate initial losses (cf. Lonmin plc, 2012). In particular, an announcement by Lonmin's management on 20 August 2012 (four days post the event) of a rights issue could have contributed to a partial recovery of the share price (Reuters, 2012b). Although the exact amount of the recovery caused by the rights announcement was not determinable from the event method applied, a general recovery of the CAR from the original event date to the six-day CAR (AR: -8.402 per cent; CAR three-day: -10.86 per cent; CAR six-day: -7.302 per cent) was noted.

A possible explanation of why the Marikana incident did not adversely affect other mining companies (Table 1; Appendix A) is that the South African mining sector had already seen strike action before the event date (McClenaghan, 2012). A wildcat strike broke out at Lonmin's mines on 10 August 2012 and on 11 August 2012 (five days before the event date), and the company applied for a court interdict giving workers until 16 August 2012 to return to their posts (Nkosi, 2012; Bond \& Mottiar, 2013). Consequently, labour unrest had already been taken into account when pricing the equity instruments of the South African mining organisations given that the JSE was at least semi-strong form efficient (Glass \& Smit, 1995; Choudhry, 1999; Jefferis et al., 1999; Magnusson \& Wydick, 2002). Therefore, the researchers decided to expand the analysis by testing 
for abnormal returns five days before the Marikana incident. Table 4 shows companies with fiveday CARs significant at the 5 per cent and 1 per cent level. (For robustness, the CARs were calculated for all companies included on the JSE).

Table 4

Summary of significant results pre Marikana

\begin{tabular}{|l|c|c|c|c|}
\hline \multicolumn{1}{|c|}{ Row labels } & CAR 5 days & $\begin{array}{c}\text { Significant at } \\
\text { the 95\% } \\
\text { prenfidence } \\
\text { level? }\end{array}$ & $\begin{array}{c}\text { Significant at } \\
\text { the 99\% } \\
\text { confidence } \\
\text { level? }\end{array}$ & $\begin{array}{c}\text { Included in } \\
\text { the mining } \\
\text { sector? }\end{array}$ \\
\hline Resilient Property Income & $-5.04 \%$ & Yes & No & No \\
\hline Allied Electronics Cor-A Shr & $10.95 \%$ & Yes & No & No \\
\hline Mas Real Estate Inc & $-6.19 \%$ & Yes & No & No \\
\hline Rebosis Property Fund Ltd & $-14.18 \%$ & Yes & No & No \\
\hline Pan African Resources Plc & $9.69 \%$ & Yes & No & No \\
\hline Synergy Income Fund Ltd-B & $-3.74 \%$ & Yes & No & No \\
\hline African \& Overseas Ent-N Shs & $-3.12 \%$ & Yes & No & No \\
\hline Sb Copper Etn & $13.59 \%$ & Yes & No & No \\
\hline Newwave Pound Sterling Etn & $13.79 \%$ & Yes & No & No \\
\hline Great Basin Gold Ltd & $-58.70 \%$ & Yes & No & Yes \\
\hline Alert Steel Holdings Ltd & $72.86 \%$ & Yes & No & No \\
\hline
\end{tabular}

Pan African Resources plc and GBG were the only mining companies reporting CARs for a fiveday period before the event date which were significant at 5 per cent, but only GBG experienced a significant abnormal return at the 1 per cent level. This would suggest that earlier strike action five days before Marikana did not have a material effect on the South African mining industry. In turn, this implies that it was only the unusually violent nature of these worker demonstrations which was taken into account by the market. In addition, many of the happenings on 16 August 2012 were associated directly with Lonmin. Other mining houses were not directly involved in the worker unrest and shootings on that day (see Evans, 2013; Smith, 2013). This also sheds light on why the CARs (post the event) are only significant at the 10 per cent level (Table 3 ) and why there was no significant sale of South African equities and bonds by foreign investors post 16 August 2012 (Section 4). Although the Marikana incident was an extraordinary event, it did not, as such, have a prolonged effect on share returns (see Chen \& Siems, 2004).

A more optimistic (and very normative) assessment is that, paradoxically, the Marikana incident was a vote of confidence in the South African mining industry. Limited social responsibility practices (including labour relations) were a possible factor contributing to the Marikana incident ${ }^{8}$. In line with the findings of De Klerk and De Villiers (2012), investors interpreting the incident as a possible indicator of limited CSR practices - may have chosen to revise their projected earnings, leading to a significant reduction in the share price of affected companies (cf. King, 2012; Solomon \& Maroun, 2014). With the JSE being only semi-strong form efficient, the initial adjustment to the share price was imperfect (cf. Malkiel \& Fama, 1970) and was revised over the six days following the event, leading to a reduction in cumulative abnormal returns (Table 1).

The importance of CSR for the South African mining sector is, however, not a recent phenomenon, with the mining industry taking significant steps to improve its ESG practices (Hamann, 2004; Carels, Maroun \& Padia, 2014). Although there is room for improvement (Hamann \& Kapelus, 2004), King-III and the integrated reporting initiative have served to reiterate the importance of CSR-related matters for the country's mining houses, including the effective and ethical management of labour (Solomon \& Maroun, 2012; Carels et al., 2014). When the happenings of 16 August 2012 make the news and the effect on mining company's share prices is limited, this suggests that investors had confidence in the CSR policies of the sector as a whole. For markets which are at least semi-strong form efficient, investors are predicted to react to new 
information by adjusting their assessment of the current and future prospects, not just of Lonmin, but for all mining companies listed on the JSE (cf. Fama et al., 1969). Had investors felt that poor labour relations (and social responsibility practices) were widespread, and that the Marikana incident was indicative of a more pervasive challenge to the mining industry, the market would have reacted by discounting the price of all shares in the mining sectors. Similarly, there would have been a significant and prolonged exit of foreign investors from the South African bond and equity markets. This was, however, not the case (Section 4). Accordingly, Marikana does not appear to have characterised the relationship between the mining houses and labour in the long term, suggesting that the efforts at good corporate governance in South Africa's mining industry are having a positive effect.

\section{Conclusion}

The objective of this paper was to examine the potential effect of the Marikana incident on the share prices of mining companies listed on the JSE. Labour unrest, culminating in the death of several mineworkers on 16 August 2012, made both local and international news and led to a material decline in the price of Lonmin shares. The unprecedented violence (post democracy) also led some to questioning whether the Marikana incident marked the beginning of the decline of South Africa's legendry mining industry (Cawadas \& Mitchell, 2012). The findings of this study suggest that this was not the case.

Although event methodology cannot be used to prove a causal relationship, Lonmin was directly affected by the event under review. The company's staff were involved in labour unrest and the mine reported significant lost production because of the strike action. As a result, it is reasonable to conclude that the significant decline in share price (and level of cumulative abnormal returns) was a result of the Marikana incident. The event has not, however, had a prolonged effect on the company's share price, as indicated by the three- and six-day CARs, which are not significant at the 1 per cent and 5 per cent level. Similarly, the CARs and results from a sign and rank test confirm that the platinum and entire mining sector did not treat the event as a significant incident, with only two gold-mining companies reporting variances which were significant at the 1 per cent or 5 per cent level. In both instances, a review of the financial press suggested that it was more likely that these variances were attributable to factors other than the event under review.

This research also offered possible explanations for the lack of sustained and widespread market reaction to the Marikana incident. Most notably, labour disputes are not uncommon in the South African mining industry. Given that the JSE is semi-strong form efficient, the probability of strike action would have already been included in share prices. In other words, the market was reacting only to the unexpected (and short-lived) violence which erupted. The results of this study may also be interpreted as a vindication of the CSR initiatives of the South African mining sector as a whole. Carels et al. (2014) and Solomon and Maroun $(2012 ; 2014)$ propose that there has been a concerted effort by South African mining companies to manage actively their social, environmental and ethical obligations. Although there is still room for improvement (Hamann, 2004; Carels et al., 2014), the absence of significant and abnormal and cumulative abnormal returns implies that investors have confidence in the CSR initiatives of the mining industry and do not regard Marikana as an indicator of a widespread CSR crisis in the South African mining sector.

The researchers acknowledge that this conclusion is very normative and not supported by an econometric analysis of the value relevance of CSR and the extent to which this may have offset the market's initial reaction to Marikana. This is an inherent limitation of the study. Nevertheless, it is submitted that the positive assessment of governance practices by the mining houses is, at the very least, a plausible explanation for why share prices did not lose significant value in the immediate aftermath of Marikana.

In the light of this, the paper makes an important contribution, not by quantifying the financial impact of investors' perceptions of CSR, but by adding to the debate on the importance of these 
practices for organisational sustainability. Additional research will be needed to reach more definitive conclusions. Most notably, more needs to be done to understand the extent to which CSR reporting and disclosure impacts share prices, given the limited South African-specific research and the mixed results from international studies (cf. De Klerk \& De Villiers, 2012). This should be complemented by more rigorous statistical modelling of the multiple variables which may have contributed to changes in the share price immediately after the Marikana incident, and how these variables impacted the share price over a longer time period. As part of this assessment, the relevance of the country's sociopolitical context, including significant levels of poverty, cannot be overlooked (cf. Lonmin plc, 2012).

The research also stops short of carrying out detailed interviews with key stakeholders to highlight more clearly the views on the relevance of the Marikana incident. It would be very interesting to ask analysts how exactly they adjusted their investment strategies in response to Marikana, and what impact the event has had on their assessment of the mining houses' prospects. This should be complemented by detailed interviews with representatives from Lonmin and worker unions in order to reach a more informed conclusion on the state of labour relations in South African mining and the relevance of CSR practices on the part of the leading mining houses.

Endnotes

1 We concentrate on companies included in the platinum-mining sector, given the direct impact of the strike action on Lonmin plc, the world's third-largest producer of platinum.

2 We say "suggest" to emphasise the normative tone of this statement. We offer effective CSR strategies as a possible explanation for any null finding (Section 5), but cannot state that there is a causal relationship between CSR and share prices or that effective CSR resulted (in a positivist sense) in a limited market reaction to Marikana.

3 No statistically significant correlations are to be found on the date of the withdrawal announcements, but the cumulative abnormal returns are significantly negative over 41-, 31-, 21- and 13-day periods (Meznar et al., 1994).

4 It is possible that impression management influences the value relevance of CRR, which may be disconnected from actua sustainability practices. Exploring this line of thinking is, however, beyond the scope of this research.

5 Owing to the fact that the entire population of mining companies was tested, cross-sectional variance adjustments to the test data were deemed unnecessary (Corrado, 2011).

6 The isolated nature of the incident also negates the need for testing the entire population of JSE-listed companies. Similarly, the fact that only a limited number of companies reported statistically significant changes in share prices during the event period meant that testing for the effect of company-specific variables (such as company size, composition of the board, length of trading, and reported results) was not necessary.

7 The IB TOP40 TRI ETN OCT17 and BETTABETA EQ WEIGHT TOP40 reported signif-icant ARs at the $1 \%$ level. Exchange-traded notes, exchange-traded funds and indices were, however, excluded from the analysis. as they would indirectly include the effects of changes in share prices on the underlying assets.

8 The researchers would like to stress that factors contributing to the Marikana incident were very complex. We are suggesting that possible CSR practices (including labour relations challenges) at Lonmin may have contributed to the events taking place on 16 August 2012. It is not, however, our intention to make normative claims about the parties responsible for the Marikana incident or the adequacy of Lonmin's CSR initiatives.

\section{Acknowledgements}

The authors would like to thank Lelys Maddock for her invaluable editorial services and Professors Robert Garnett and Linda de Beer for comments on earlier versions of this paper. Thanks also go to the participants of the Meditari Accountancy Research Conference (South Africa, 2014) and the Macrotheme Economic Review (France, 2014) for their comments on drafts of this research.

\section{References}

ATKINS, J. \& MAROUN, W. 2014. South African institutional investors' perceptions of integrated reporting. Published in ACCA (ed.). London: The Association of Chartered Certified Accountants. ATKINS, J. \& MAROUN, W. 2015. Integrated reporting in South Africa in 2012: Perspectives from South African institutional investors. Meditari Accountancy Research, 23(2):197-221.

BARCLAY, M.J. \& LITZENBERGER, R.H. 1988. Announcement effects of new equity issues and the use of intraday price data. Journal of Financial Economics, 21(1):71-99.

BASU, 1977. Investment performance of common stocks in relation to their price-earnings ratios: A test of the efficient market hypothesis. The Journal of Finance, 32(3):663-682. 
BATEMAN, M. 2012. Microcredit and Marikana: How they are linked. Available at: http://www.iol.co.za/ the-star/microcredit-and-marikana-how-they-are-linked-1.1385126\#.UiekoNKnoQg [accessed 2013-09-04]. BERLE, A. \& MEANS, G. 1932. The modern corporation and private property. New Brunswick, New Jersey: Harcourt Brace.

BHANA, N. 2005. The share price reaction to management buyout announcements of companies listed on the JSE Securities Exchange. Investment Analysts Journal, 62(1):19-30.

BHANA, N. 2006. The effect of corporate divestments on shareholder wealth: The South African experience. Investment Analysts Journal, 63(1):19-30.

BHANA, N. 2007. The market reaction to open market share repurchases announcements: The South African experience. Investment Analysts Journal, 65(1):25-36.

BINDER, J. 1998. The event study methodology since 1969. Review of Quantitative Finance and Accounting, 11(2):111-137.

BLUME, L., EASLEY, D. \& O'HARA, M. 1994. Market statistics and technical analysis: The role of volume. The Journal of Finance, 49(1):153-181.

BOND, P. \& MOTTIAR, S. 2013. Movements, protests and a massacre in South Africa. Journal of Contemporary African Studies, 31(2):283-302.

BOWMAN, R.G. 1983. Understanding and conducting event studies. Journal of Business Finance \& Accounting, 10(4):561-584.

BREALEY, R., MYERS, S. \& ALLEN, F. 2008. Principles of corporate finance. Boston: McGraw Hill. BROWN, S.J. \& WARNER, J.B. 1980. Measuring security price performance. Journal of Financial Economics, 8(3):205-258.

BROWN, S.J. \& WARNER, J.B. 1985. Using daily stock returns: The case of event studies. Journal of Financial Economics, 14(1):3-31.

BUYS, P., BOSMAN, P. \& VAN ROOYEN, S. 2009. Do socially conscious companies provide better financial performance? An exploratory study. Studia Universitatis Babes Bolyai-Oeconomica, 1:3-15. CAPELLE-BLANCARD, G. \& LAGUNA, M.-A. 2010. How does the stock market respond to chemical disasters? Journal of Environmental Economics and Management, 59(2):192-205.

CARELS, C., MAROUN, W. \& PADIA, N. 2014. Integrated reporting in the South African mining sector. Corporate Ownership and Control, 11(1):991-1005.

CARROLL, A.B. \& SHABANA, K.M. 2010. The business case for corporate social responsibility: A review of concepts, research and practice. International Journal of Management Reviews, 12(1):85-105.

CAWADAS, D. \& MITCHELL, A. 2012. Marikana - the causes and wider implications and lessons for the mining industry in Africa. Available at: http://www.fasken.com/en/marikana/ [accessed 2013-09-04].

CHAMBERS, A.E. \& PENMAN, S.H. 1984. Timeliness of reporting and the stock price reaction to earnings announcements. Journal of Accounting Research, 22(1):21-47.

CHEN, A.H. \& SIEMS, T.F. 2004. The effects of terrorism on global capital markets. European Journal of Political Economy, 20(2):349-366.

CHEN, G., WANG, B. \& WANG, X.S. 2014. Corporate social responsibility and the informativeness of stock prices. Available at: http://www.fma.org/Nashville/Papers/CSR_INFO_20140114.pdf [accessed 2014/02/15].

CHINGUNO, C. 2013. Marikana massacre and strike violence post-apartheid. Global Labour Journal, 4(2):160-166.

CHOUDHRY, T. 1999. Re-examining forward market efficiency: Evidence from fractional and Harris-Inder cointegration tests. International Review of Economics \& Finance, 8(4):433-453.

CLARKE, J., JANDIK, T. \& MANDELKER, G. 2001. The efficient markets hypothesis. Published in R. Arffa (ed.), Expert financial planning: Advice from industry leaders, 126-141.

CORRADO, C.J. 1989. A nonparametric test for abnormal security-price performance in event studies. Journal of Financial Economics, 23(2):385-395.

CORRADO, C.J. 2011. Event studies: A methodology review. Accounting \& Finance, 51(1):207-234.

DE KLERK, M. \& DE VILLIERS, C. 2012. The value relevance of corporate responsibility reporting: South African evidence. Meditari Accountancy Research, 20(1):21-38. 
DONNELLY, R. 2008. Accounting, board independence and contagion effects from adverse press comment: The case of Elan. The British Accounting Review, 40(3):245-259.

ERNST \& YOUNG. 2012. Ernst \& Young's Excellence in Integrated Reporting Awards 2012. Available at: http://www.ey.com/Publication/vwLUAssets/Excellence_in_Integrated_Reporting_Awards_2012/\$FILE/120 830\%20Excellence.indd.pdf [accessed 2011/04/02].

EVANS, S. 2013. Marikana: Farlam Commission's credibility on the rocks. Available at: http://mg.co.za/article/2013-08-13-marikana-farlam-commissions-credibility-is-on-the-rocks [accessed 2013/08/17].

FAMA, E.F. 1965. Random walks in stock market prices. Financial Analysts Journal, 21(5):55-59.

FAMA, E., FISHER, L., JENSEN, M. \& ROLL, R. 1969. The adjustment of stock prices to new information. International Economic Review, 10(1):1-21.

FLAMMER, C. 2013. Corporate social responsibility and shareholder reaction: The environmental awareness of investors. Academy of Management Journal, 56(3):758-781.

FRANKEL, P. 2012. Marikana: 20 years in the making. Business Report. Available at. http://www.iol.co.za/ business/opinion/marikana-20-years-in-the-making-1.1407448 [accessed 2013/11/30].

FREEMAN, E. 1984. Strategic management: A stakeholder approach. Boston: Pittman.

GLASS, R. \& SMIT, E. 1995. The relationship between changes in the money supply and changes in share prices: The semi-strong form efficiency of the Johannesburg Stock Exchange revisited. South African Journal of Business Management, 26(1):131-140.

GREGORY, A., THARYAN, R. \& WHITTAKER, J. 2013. Corporate social responsibility and firm value: Disaggregating the effects on cash flow, risk and growth. Journal of Business Ethics, 124(4):1-25.

GRIFFIN, J.J. \& MAHON, J.F. 1997. The corporate social performance and corporate financial performance debate: Twenty-five years of incomparable research. Business \& Society, 36:5-31.

HAMANN, R. 2004. Corporate social responsibility, partnerships, and institutional change: The case of mining companies in South Africa. Natural Resources Forum, 28:278-290.

HAMANN, R. \& KAPELUS, P. 2004. Corporate social responsibility in mining in Southern Africa: Fair accountability or just greenwash? Development, 47(3):85-92.

HAMILTON, J.T. 1995. Pollution as news: Media and stock market reactions to the toxics release inventory data. Journal of Environmental Economics and Management, 28(1):98-113.

HAND, J.R., HOLTHAUSEN, R.W. \& LEFTWICH, R.W. 1992. The effect of bond rating agency announcements on bond and stock prices. The Journal of Finance, 47(2):733-752.

HARVEY, C. \& STICHT, P. 2014. Financial dictionary [online]. Available at: http://financialdictionary.thefreedictionary.com/Alpha [accessed 2014/01/15].

HASSEL, L., NILSSON, H. \& NYQUIST, S. 2005. The value relevance of environmental performance. European Accounting Review, 14(1):41-61.

HOVAV, A. \& D'ARCY, J. 2003. The impact of denial-of-service attack announcements on the market value of firms. Risk Management and Insurance Review, 6(2):97-121.

IOD (Institute of Directors in Southern Africa). 2009. The King code of governance for South Africa (2009) and King report on governance for South Africa (2009) (King-III). Johannesburg, South Africa: Lexis Nexus South Africa.

IOD (Institute of Directors in Southern Africa). 2011. Code for responsible investing in South Africa. Available at: http://c.ymcdn.com/sites/www.iodsa.co.za/resource/resmgr/crisa/crisa_19_july_2011.pdf [accessed 5 June 2012].

IRCSA (Integrated Reporting Committee of South Africa). 2011. Framework for integrated reporting and the integrated report. Available at: www.sustainabilitysa.org [accessed 2012/06/05].

JEFFERIS, K. \& SMITH, G. 2004. Capitalisation and weak-form efficiency in the JSE securities exchange. South African Journal of Economics, 72(4):684-707.

JEFFERIS, K., OKEAHALAM, C. \& MATOME, T. 1999. International stock market linkages in Southern Africa. The African Economic Research Consortium 2001. Gaborone: Botswana Institute for Development Policy Analysis.

JENSEN, M.C. \& MECKLING, W.H. 1976. Theory of the firm: Managerial behavior, agency costs and ownership structure. Journal of Financial Economics, 3(4):305-360. 
JONES, S., FROST, G., LOFTUS, J. \& VAN DER LAAN, S. 2007. An empirical examination of the market returns and financial performance of entities engaged in sustainability reporting. Australian Accounting Review, 17(41):78-87.

JSE (Johannesburg Stock Exchange). 2013. JSE listing requirements. Available at: http://www.jse.co.za/ How-To-List/Listing-requirements/JSE-listing-requirements.aspx [accessed 2013/02/01].

KALRA, R., HENDERSON Jr G.V. \& RAINES, G.A. 1993. Effects of the Chernobyl nuclear accident on utility share prices. Quarterly Journal of Business and Economics, 32(2):52-77.

KING, M.E. 2012. Comments on: Integrated reporting and the integrated report. Public lecture. International Corporate Governance Conference. Johannesburg, South Africa, 23 October.

KOLARI, J.W. \& PYNNÖNEN, S. 2010. Event study testing with cross-sectional correlation of abnormal returns. Review of Financial Studies, 23(11):3996-4025.

KOTHARI, S. \& WARNER, J. 2006. The econometrics of event studies. Handbook of Empirical Corporate Finance, 1:4-32.

KUMAR, R., LAMB, W.B. \& WOKUTCH, R.E. 2002. The end of South African sanctions, institutional ownership, and the stock price performance of boycotted firms: Evidence on the impact of social/ethical investing. Business \& Society, 41(2):133-165.

LAMB, W.B., KUMAR, R. \& WOKUTCH, R.E. 2005. Corporate social performance and the road to redemption: Insights from the South Africa sanctions. Organizational Analysis, 13(1):1-14.

LINTNER, J. 1965. The valuation of risk assets and the selection of risky investments in stock portfolios and capital budgets. The Review of Economics and Statistics, 47(1):13-37.

LONMIN PLC. 2012. Lonmin responds to Philip Frankel's article: Marikana: 20 years in the making. Available at: http://www.lonminmarikanainfo.com/news_article.php?articleID=1384 [accessed 2013/11/30].

MABUSE, N. 2012. Rising tensions explode into grisly violence at South African mine. Available at: http://edition.cnn.com/2012/08/16/world/africa/south-africa-mine-violence/index.html?iref=allsearch [accessed 2014/02/24].

MACKINLAY, A.C. 1997. Event studies in economics and finance. Journal of Economic Literature, 35(1):13-39.

MAGNUSSON, M. \& WYDICK, B. 2002. How efficient are Africa's emerging stock markets? Journal of Development Studies, 38(4):141-156.

MALKIEL, B.G. \& FAMA, E.F. 1970. Efficient capital markets: A review of theory and empirical work. The Journal of Finance, 25(2):383-417.

MALKIEL, B.G. 2003. The efficient market hypothesis and its critics. Journal of Economic Perspectives, 7(1):59-82.

MARINOVICH, G. 2012. The murder fields of Marikana. The cold murder fields of Marikana. The Daily Maverick [online]. Available at: http://www.dailymaverick.co.za/article/2012-08-30-the-murder-fields-ofmarikana-the-cold-murder-fields-of-marikana\#.VkNFWG7Tp2A [accessed 2013/09/25].

MCCLENAGHAN, M. 2012. South African massacre was the tip of an iceberg. Available at: http://www.thebureauinvestigates.com/2012/10/18/south-african-massacre-was-the-tip-of-an-iceberg/ [accessed 2013/09/18].

MCWILLIAMS, A. \& SIEGEL, D. 1997. Event studies in management research: Theoretical and empirical issues. Academy of Management Journal, 40:626-657.

MEZNAR, M.B., NIGH, D. \& KWOK, C.C.Y. 1994. Effect of announcements of withdrawal from South Africa. Academy of Management Journal, 37(6):1633.

MEZNAR, M.B., NIGH, D. \& KWOK, C.C.Y. 1998. Announcements of withdrawal from South Africa revisited: Making sense of contradictory event study findings. Academy of Management Journal, 41(6): 715-730.

NKOSI, M. 2012. South Africa's Lonmin Marikana mine clashes killed 34. Available at: http://www.bbc. co.uk/news/world-africa-19292909 [accessed 2013/09/04].

ONSLOW, S. 2012. Book review: Who rules South Africa? LSE Review of Books [online]. Available at: $\mathrm{http}: / /$ blogs.lse.ac.uk/lsereviewofbooks/2012/09/17/who-rules-south-africa-martin-plaut-and-paul-holden/ [accessed 2013/09/17]. 
PATELL, J.M. 1976. Corporate forecasts of earnings per share and stock price behavior: Empirical test. Journal of Accounting Research, 14(2):246-276.

PATTEN, D.M. 1992. Intra-industry environmental disclosures in response to the Alaskan oil spill: A note on legitimacy theory. Accounting, Organizations and Society, 17(5):471-475.

PATTEN, D.M. 2002. The relation between environmental performance and environmental disclosure: A research note. Accounting, Organizations and Society, 27(8):763-773.

Economic Policy, 15(1):76-86.

REUTERS. 2012a. Great Basin up for sale amid liquidity crunch. Available at: http://www.miningreview. com/great-basin-up-for-sale-amid-liquidity-crunch/ [accessed 2014/02/09].

REUTERS. 2012b. Lonmin considers \$1billion rights issue. Available at: http://www.miningreview.com/ lonmin-considers-1billion-rights-issue/ [accessed 2014/02/09].

REUTERS. 2012c. Lonmin shares tumble. Available at: http://www.iol.co.za/business/companies/lonminshares-tumble-1.1364086\#.UieWJdKnoQh [accessed 2013/09/04].

ROMAN, R.M., HAYIBOR, S. \& AGLE, B.R. 1999. The relationship between social and financial performance: Repainting a portrait. Business \& Society, 38:109-125.

ROSEN, R.J. 2006. Merger momentum and investor sentiment: The stock market reaction to merger announcements. The Journal of Business, 79(2):987-1017.

ROSS, S.A. 1976. The arbitrage theory of capital asset pricing. Journal of Economic Theory, 13(3):341-360.

SCHWERT, G.W. 1981. The adjustment of stock prices to information about inflation. The Journal of Finance, 36(1):15-29.

SHARPE, W.F. 1964. Capital asset prices: A theory of market equilibrium under conditions of risk. The Journal of Finance, 19(3):425-442.

SMITH, M. 2013. The Marikana massacre and lessons for the left. Irish Marxist Review, 2(5):53-64.

SOLOMON, J. 2010. Corporate governance and accountability (3rd ed.) West Sussex, United Kingdom: John Wiley \& Sons.

SOLOMON, J. \& MAROUN, W. 2012. Integrated reporting: The new face of social, ethical and environmental reporting in South Africa? Published in ACCA (ed.) London: The Association of Chartered Certified Accountants.

SOLOMON, J. \& MAROUN, W. 2014. South African investors' and analysts' reactions to integrated reporting. Published in ACCA (ed.) London: The Association of Chartered Certified Accountants.

SORENSEN, P. 2012. The Marikana tragedy. International Journal of Environmental Studies, 69(6): 871-873.

SPRENGER, T.O., SANDNER, P.G., TUMASJAN, A. \& WELPE, I.M. 2014. News or noise? Using Twitter to identify and understand company-specific news flow. Journal of Business Finance \& Accounting, 41(78):791-830.

STANLEY, C. 2012. Central Rand gold. Available at: http://www.africanmining.com/sx_1!net474/upload/ Analyst\%20Report\%2015\%20August\%202012.pdf [accessed 2014/02/17].

TEOH, SIEW H., WELCH, I. \& WAZZAN, C.P. 1999. The effect of socially activist investment policies on the financial markets: Evidence from the South African boycott. The Journal of Business, 72(1):35-89.

THE MARIKANA COMMISSION OF INQUIRY. 2013. About the commission. Available at: http://www.marikanacomm.org.za/ [accessed. 2013/11/30].

ULLMANN, A.A. 1985. Data in search of a theory: A critical examination of the relationships among social performance, social disclosure, and economic performance of U.S. firms. Academy of Management Review, 10:540-557.

VAN GRAAN, M. 2013. The spear and the Marikana massacre: Mirroring the decline of South African democracy. African Arts, 46(2):1-4.

WHITE, M.A. 1996. Investor response to the Exxon Valdez oil spill. University of Virginia [online]. Available at: http://www.environmental-expert.com/Files\%5C0\%5Carticles\%5C2611\%5CWhite.pdf [accessed 2013/09/25].

WOOD, D.J., \& JONES, R.E. 1995. Stakeholder mismatching: A theoretical problem in empirical research on corporate social performance. International Journal of Organizational Analysis, 3:229-267. 
WORRELL, D.L. \& DAVIDSON, W.N. 1987. The effect of CEO succession on stockholder wealth in large firms following the death of the predecessor. Journal of Management, 13(3):509-515.

WRIGHT, P. \& FERRIS, S. 1997. Agency conflict and corporate strategy. The effect of disinvestment on corporate value. Strategic Management Journal, 18:77-83.

\section{Appendix A}

\section{Abnormal and cumulative abnormal returns for JSE-listed mining houses}

Table A

General mining sector

\begin{tabular}{|c|c|c|c|c|}
\hline Share code & Company name & AR & CARs 3-day & CARs 6-day \\
\hline WEZ & Wesizwe Platinum Ltd & $-2.997 \%$ & $0.186 \%$ & $12.166 \% *$ \\
\hline PAN & Pan African Resources Plc & $2.466 \% *$ & $-6.460 \%{ }^{*}$ & $-2.619 \%$ \\
\hline DRN & Delrand Resources Ltd & $-0.171 \%$ & $-0.880 \%$ & $-1.516 \%$ \\
\hline KEH & Keaton Energy Holdings Ltd & $-1.667 \%$ & $-5.046 \%$ & $-12.268 \%^{*}$ \\
\hline RBP & Royal Bafokeng Platinum Ltd & $-2.236 \% *$ & $-4.239 \%^{*}$ & $-4.976 \% *$ \\
\hline CZA & Coal Of Africa Ltd & $-1.220 \%$ & $-4.686 \%$ & $-10.346 \% *$ \\
\hline FSE & Firestone Energy Ltd & $-0.615 \%$ & $0.667 \%$ & $-12.112 \%$ \\
\hline VIL & Village Main Reef Ltd & $-0.188 \%$ & $-3.481 \%$ & $-0.548 \%$ \\
\hline $\mathrm{CMO}$ & Chrometco Ltd & $0.302 \%$ & $-13.187 \%$ & $-12.321 \%$ \\
\hline EPS & Eastern Platinum Ltd & $-8.076 \%$ & $-6.534 \%$ & $3.981 \%$ \\
\hline $\mathrm{MMH}$ & Miranda Mineral Holdings Ltd & $4.588 \%$ & $5.305 \%$ & $-0.011 \%$ \\
\hline BDM & Buildmax Ltd & $-7.772 \%$ & $-7.575 \%$ & $-0.939 \%$ \\
\hline CRD & Central Rand Gold Ltd & $20.696 \%$ ** & $29.555 \%{ }^{*}$ & $12.841 \%$ \\
\hline DMC & Diamondcorp Plc & $0.852 \%$ & $1.024 \%$ & $3.067 \%$ \\
\hline FSEO1 & Firestone Energy Ltd & $1.126 \%$ & $1.039 \%$ & $3.633 \%$ \\
\hline FMC & Forbes And Manhattan Coal Corp. & $0.712 \%$ & $0.830 \%$ & $2.527 \%$ \\
\hline HWA & Hwange Colliery Company Ltd & $0.636 \%$ & $0.438 \%$ & $1.852 \%$ \\
\hline PZG & Pamdzi Gold Ltd & $0.000 \%$ & $0.000 \%$ & $0.000 \%$ \\
\hline GBG & Great Basin Gold Ltd & $-20.171 \%$ *** & $-19.151 \% *$ & $-13.007 \%$ \\
\hline JBL & Jubilee Platinum Plc & $0.198 \%$ & $2.336 \%$ & $-0.190 \%$ \\
\hline IRA & Infrasors Holdings Ltd & $-8.261 \%$ & $-13.245 \%$ & $-5.383 \%$ \\
\hline RDI & Rockwell Diamonds Inc. & $0.117 \%$ & $0.516 \%$ & $0.923 \%$ \\
\hline BIL & Bhp Billiton Plc & $0.651 \%$ & $2.010 \%$ & $2.155 \%$ \\
\hline EXX & Exxaro Resources Ltd & $-2.465 \%$ & $-0.632 \%$ & $-2.585 \%$ \\
\hline AQP & Aquarius Platinum Ltd & $0.973 \%$ & $6.242 \%$ & $19.932 \% *$ \\
\hline $\mathrm{SAH}$ & South African Coal Mining Holdings & $0.909 \%$ & $3.499 \%$ & $1.146 \%$ \\
\hline KBO & Kibo Mining Plc & $0.740 \%$ & $1.734 \%$ & $0.374 \%$ \\
\hline UUU & Uranium One Inc. & $5.151 \%$ & $6.549 \%$ & $6.517 \%$ \\
\hline PLL & Platfields Ltd & $-29.524 \%$ & $1.469 \%$ & $0.456 \%$ \\
\hline GGM & Goliath Gold Mining Ltd & $-0.204 \%$ & $0.318 \%$ & $-2.513 \%$ \\
\hline 1 & Randgold \& Exploration Company Ltd & $-0.260 \%$ & $-24.230 \% *$ & $--24.786 \% *$ \\
\hline RSG & Resource Generation Ltd & $0.000 \%$ & $0.000 \%$ & $0.000 \%$ \\
\hline BAU & Bauba Platinum Ltd & $0.166 \%$ & $-16.279 \%$ & $1.657 \%$ \\
\hline WSL & Wescoal Holdings Ltd. & $1.045 \%$ & $-2.421 \%$ & $-3.659 \%$ \\
\hline TAW & Tawana Resources NI & $-0.643 \%$ & $-0.880 \%$ & $-2.457 \%$ \\
\hline WGR & Witwatersrand Consolidated Gold Resources & $-0.157 \%$ & $1.011 \%$ & $1.037 \%$ \\
\hline SEP & Sephaku Holdings Ltd & $0.753 \%$ & $3.181 \%$ & $1.476 \%$ \\
\hline TSX & Trans Hex Group Ltd & $-1.452 \%$ & $2.926 \%$ & $-3.515 \%$ \\
\hline DRD & Drdgold Ltd & $-1.144 \%$ & $1.130 \%$ & $1.061 \%$ \\
\hline GDO & Gold One International Ltd & $-2.507 \%$ & $0.169 \%$ & $-0.982 \%$ \\
\hline ANG & Anglogold Ashanti Ltd & $2.436 \%$ & $2.009 \%$ & $1.589 \%$ \\
\hline HAR & Harmony Gold Mining Company Ltd & $1.516 \%$ & $-10.177 \% *$ & $-4.116 \%$ \\
\hline GFI & Gold Fields Ltd & $1.379 \%$ & $0.798 \%$ & $0.599 \%$ \\
\hline
\end{tabular}




\begin{tabular}{|c|c|c|c|c|}
\hline Share code & Company name & AR & CARs 3-day & CARs 6-day \\
\hline IMP & Impala Platinum Holdings Ltd & $-1.642 \%$ & $1.351 \%$ & $2.462 \%$ \\
\hline NHM & Northam Platinum Ltd & $-2.480 \%$ & $-1.703 \%$ & $6.324 \% *$ \\
\hline AMS & Anglo American Plat Ltd & $-1.008 \%$ & $-1.126 \%$ & $2.871 \%$ \\
\hline AGL & Anglo American Plc & $0.403 \%$ & $0.876 \%$ & $2.262 \%$ \\
\hline ARI & African Rainbow Minerals Ltd & $1.811 \%$ & $1.379 \%$ & $-0.911 \%$ \\
\hline ASR & Assore Ltd & $-0.485 \%$ & $2.971 \%$ & $5.035 \%$ \\
\hline MRF & Merafe Resources Ltd & $-0.191 \%$ & $0.406 \%$ & $0.161 \%$ \\
\hline LON & Lonmin Plc & $-8.402 \%{ }^{* * *}$ & $-10.86 \% *$ & $-7.302 \% *$ \\
\hline ATL & Atlatsa Resources Corp. & $-11.122 \%$ & $3.128 \%$ & $7.479 \%$ \\
\hline PET & Petmin Ltd & $-0.172 \%$ & $-4.378 \%$ & $-8.850 \% *$ \\
\hline SNU & Sentula Mining Ltd & $0.082 \%$ & $0.611 \%$ & $-2.008 \%$ \\
\hline
\end{tabular}

${ }^{*}$ Significant at a $90 \%$ confidence level; ${ }^{* *}$ Significant at a $95 \%$ confidence level; ${ }^{* * *}$ Significant at a $99 \%$ confidence level

\section{Appendix B}

\section{Sign and rank tests}

Table B1

Sign t-tests

\begin{tabular}{|c|c|c|c|c|}
\hline Company name & $\hat{\boldsymbol{p}}$ & AR & CAR 3 & CAR 6 \\
\hline Wesizwe Platinum Ltd. & 0.57931 & - & + & + \\
\hline Pan African Resources Plc & 0.468966 & + & - & - \\
\hline Delrand Resources Ltd & 0.055172 & - & - & - \\
\hline Keaton Energy Holdings Ltd & 0.627586 & - & - & - \\
\hline Royal Bafokeng Platinum Ltd & 0.482759 & - & - & - \\
\hline Coal Of Africa Ltd & 0.544828 & - & - & - \\
\hline Firestone Energy Ltd & 0.468966 & - & + & - \\
\hline Village Main Reef Ltd & 0.510345 & - & - & - \\
\hline Chrometco Ltd & 0.772414 & + & - & - \\
\hline Eastern Platinum Ltd & 0.482759 & - & - & + \\
\hline Miranda Mineral Holdings Ltd & 0.510345 & + & + & - \\
\hline Buildmax Ltd & 0.4 & - & - & - \\
\hline Central Rand Gold Ltd & 0.593103 & + & + & + \\
\hline Diamondcorp Plc & 0.717241 & + & + & + \\
\hline Firestone Energy Ltd & 0.696552 & + & + & + \\
\hline Forbes And Manhattan Coal Corp. & 0.717241 & + & + & + \\
\hline Hwange Colliery Company Ltd & 0.641379 & + & + & + \\
\hline Great Basin Gold Ltd & 0.496552 & - & - & - \\
\hline Jubilee Platinum Plc & 0.517241 & + & + & - \\
\hline Infrasors Holdings Ltd & 0.503448 & - & - & - \\
\hline Rockwell Diamonds Inc. & 0.931034 & + & + & + \\
\hline Bhp Billiton Plc & 0.475862 & + & + & + \\
\hline Exxaro Resources Ltd & 0.510345 & - & - & - \\
\hline Aquarius Platinum Ltd & 0.572414 & + & + & + \\
\hline Uranium One Inc. & 0.475862 & + & + & + \\
\hline Platfields Ltd & 0.531034 & - & + & + \\
\hline Goliath Gold Mining Ltd & 0.475862 & - & + & - \\
\hline Randgold \& Exploration Company Ltd & 0.365517 & - & - & - \\
\hline Bauba Platinum Ltd & 0.77931 & + & - & + \\
\hline Wescoal Holdings Ltd & 0.42069 & + & - & - \\
\hline Tawana Resources NL & 0.262069 & - & - & - \\
\hline Witwatersrand Consolidated Gold Resources & 0.593103 & - & + & + \\
\hline Sephaku Holdings Ltd & 0.455172 & + & + & + \\
\hline Trans Hex Group Ltd & 0.482759 & - & + & - \\
\hline
\end{tabular}




\begin{tabular}{|c|c|c|c|c|}
\hline Company name & $\hat{p}$ & AR & CAR 3 & CAR 6 \\
\hline Drdgold Ltd & 0.524138 & - & + & + \\
\hline Gold One International Ltd & 0.6 & - & + & - \\
\hline Anglogold Ashanti Ltd & 0.489655 & + & + & + \\
\hline Harmony Gold Mining Company Ltd & 0.475862 & + & - & - \\
\hline Gold Fields Ltd & 0.468966 & + & + & + \\
\hline Impala Platinum Holdings Ltd & 0.489655 & - & + & + \\
\hline Northam Platinum Ltd & 0.537931 & - & - & + \\
\hline Anglo American Plat Ltd & 0.489655 & - & - & + \\
\hline Anglo American Plc & 0.510345 & + & + & + \\
\hline African Rainbow Minerals Ltd & 0.489655 & + & + & - \\
\hline Assore Ltd & 0.503448 & - & + & + \\
\hline Merafe Resources Ltd & 0.489655 & - & + & + \\
\hline Lonmin Plc & 0.489655 & - & - & - \\
\hline Petmin Ltd & 0.475862 & - & - & - \\
\hline Sentula Mining Ltd & 0.544828 & + & + & - \\
\hline w & & 28 & \multicolumn{2}{|c|}{24} \\
\hline \multicolumn{2}{|l|}{$n \hat{p}$} & \multicolumn{3}{|c|}{0.524419} \\
\hline & & 0.658914 & & \\
\hline
\end{tabular}

Table B2

Rank tests

\begin{tabular}{|c|c|c|c|c|c|c|}
\hline & $2012 / 08 / 16$ & $2012 / 08 / 17$ & $2012 / 08 / 20$ & $2012 / 08 / 21$ & $2012 / 08 / 22$ & $2012 / 08 / 23$ \\
\hline Wesizwe Platinum Ltd & 23 & 138 & 40 & 126 & 127 & 149 \\
\hline Pan African Resources Plc & 145 & 1 & 4 & 129 & 149 & 59 \\
\hline Delrand Resources Ltd & 108 & 41 & 53 & 134 & 143 & 9 \\
\hline Keaton Energy Holdings Ltd & 28 & 125 & 9 & 61 & 26 & 6 \\
\hline Royal Bafokeng Platinum Ltd & 11 & 62 & 12 & 17 & 103 & 95 \\
\hline Coal Of Africa Ltd & 45 & 73 & 15 & 30 & 66 & 19 \\
\hline Firestone Energy Ltd & 60 & 32 & 128 & 45 & 103 & 24 \\
\hline Village Main Reef Ltd & 70 & 76 & 14 & 145 & 53 & 32 \\
\hline Chrometco Ltd & 103 & 57 & 7 & 122 & 54 & 106 \\
\hline Eastern Platinum Ltd & 4 & 121 & 54 & 130 & 27 & 147 \\
\hline Miranda Mineral Holdings Ltd & 134 & 98 & 87 & 41 & 101 & 15 \\
\hline Buildmax Ltd & 6 & 145 & 13 & 38 & 150 & 17 \\
\hline Central Rand Gold Ltd & 148 & 61 & 126 & 109 & 3 & 95 \\
\hline Diamondcorp Plc & 109 & 41 & 56 & 136 & 39 & 112 \\
\hline Firestone Energy Ltd & 109 & 42 & 56 & 135 & 39 & 111 \\
\hline Forbes And Manhattan Coal Corp. & 110 & 41 & 56 & 136 & 38 & 114 \\
\hline Hwange Colliery Company Ltd & 108 & 44 & 56 & 132 & 41 & 110 \\
\hline Great Basin Gold Ltd & 1 & 17 & 137 & 87 & 138 & 66 \\
\hline Jubilee Platinum Plc & 77 & 87 & 113 & 3 & 125 & 112 \\
\hline Infrasors Holdings Ltd & 10 & 25 & 49 & 41 & 147 & 57 \\
\hline Rockwell Diamonds Inc. & 47 & 114 & 99 & 21 & 117 & 44 \\
\hline Bhp Billiton Plc & 116 & 146 & 68 & 49 & 89 & 102 \\
\hline Exxaro Resources Ltd & 7 & 145 & 51 & 107 & 73 & 5 \\
\hline Aquarius Platinum Ltd & 86 & 148 & 43 & 149 & 61 & 146 \\
\hline Uranium One Inc. & 141 & 129 & 41 & 19 & 139 & 46 \\
\hline Platfields Ltd & 7 & 94 & 146 & 41 & 95 & 57 \\
\hline Goliath Gold Mining Ltd & 55 & 105 & 98 & 34 & 108 & 14 \\
\hline Randgold \& Exploration Company Ltd & 55 & 107 & 1 & 39 & 109 & 52 \\
\hline Bauba Platinum Ltd & 55 & 3 & 95 & 148 & 27 & 128 \\
\hline Wescoal Holdings Ltd & 96 & 36 & 56 & 99 & 54 & 58 \\
\hline Tawana Resources NI & 44 & 110 & 96 & 16 & 113 & 40 \\
\hline
\end{tabular}




\begin{tabular}{|c|c|c|c|c|c|c|}
\hline & $2012 / 08 / 16$ & $2012 / 08 / 17$ & $2012 / 08 / 20$ & $2012 / 08 / 21$ & $2012 / 08 / 22$ & $2012 / 08 / 23$ \\
\hline $\begin{array}{l}\text { Witwatersrand Consolidated Gold } \\
\text { Resources }\end{array}$ & 53 & 108 & 97 & 28 & 109 & 50 \\
\hline Sephaku Holdings Ltd & 94 & 105 & 95 & 37 & 108 & 54 \\
\hline Trans Hex Group Ltd & 47 & 138 & 62 & 79 & 121 & 2 \\
\hline Drdgold Ltd & 44 & 137 & 55 & 42 & 77 & 109 \\
\hline Gold One International Ltd & 16 & 142 & 42 & 31 & 110 & 40 \\
\hline Anglogold Ashanti Ltd & 139 & 136 & 14 & 130 & 46 & 39 \\
\hline Harmony Gold Mining Company Ltd & 121 & 2 & 1 & 148 & 114 & 107 \\
\hline Gold Fields Ltd & 126 & 123 & 17 & 38 & 82 & 110 \\
\hline Impala Platinum Holdings Ltd & 17 & 138 & 124 & 112 & 96 & 57 \\
\hline Northam Platinum Ltd & 8 & 97 & 90 & 56 & 144 & 151 \\
\hline Anglo American Plat Ltd & 30 & 12 & 139 & 127 & 104 & 141 \\
\hline Anglo American Plc & 101 & 61 & 117 & 130 & 8 & 148 \\
\hline African Rainbow Minerals Ltd & 142 & 73 & 62 & 47 & 29 & 46 \\
\hline Assore Ltd & 53 & 99 & 145 & 27 & 105 & 143 \\
\hline Merafe Resources Ltd & 66 & 94 & 87 & 26 & 44 & 138 \\
\hline Lonmin Plc & 1 & 106 & 4 & 133 & 10 & 150 \\
\hline Petmin Ltd & 70 & 49 & 7 & 36 & 16 & 40 \\
\hline Sentula Mining Ltd & 87 & 121 & 36 & 12 & 34 & 128 \\
\hline Average rank & 68.02 & 85.81 & 62.71 & 76.69 & 81.91 & 77.55 \\
\hline Population mean rank & \multicolumn{6}{|c|}{76} \\
\hline D & \multicolumn{6}{|c|}{151} \\
\hline Generalised rank Test statistic & \multicolumn{6}{|c|}{-0.875769667} \\
\hline
\end{tabular}

\section{Appendix C}

\section{Volume of shares traded}

The volume of daily share trades serves as an indicator of the level of active trading (responsiveness) and can provide insight into the quality of information transferred by share price changes (Blume, Easley \& O'hara, 1994). Presented in Table C is the volume of trade of those shares which experienced significant abnormal returns at the 90 per cent confidence level or above (Table 3). The table shows an average volume of shares traded per day over the event window (145 days). The volume of shares traded on the date of the Marikana incident is also provided. The final column shows the event-date volume of shares traded as a percentage of the average shares traded during the estimation window.

Table C

Event volumes of shares traded

\begin{tabular}{|l|c|r|r|r|}
\multicolumn{1}{|c|}{ Company name } & Mining sector & $\begin{array}{c}\text { Average shares traded } \\
\text { during estimation } \\
\text { window (A) }\end{array}$ & $\begin{array}{c}\text { Event date } \\
\text { (B) }\end{array}$ & B/A \\
\hline Wesizwe Platinum Ltd & Plat. & 664173 & 613045 & $\mathbf{9 2 \%}$ \\
\hline Pan African Resources Plc & Gold & 2311713 & 870972 & $\mathbf{3 8 \%}$ \\
\hline Keaton Energy Holdings Ltd & Coal & 74095 & 6870 & $\mathbf{9 \%}$ \\
\hline Royal Bafokeng Platinum Ltd & Plat. & 88155 & 3279 & $\mathbf{4 \%}$ \\
\hline Coal Of Africa Ltd & Coal & 688332 & 67208 & $\mathbf{1 0 \%}$ \\
\hline Central Rand Gold Ltd & Gold & 350088 & 1000 & $\mathbf{0 \%}$ \\
\hline Great Basin Gold Ltd & Gold & 68831 & 505476 & $\mathbf{7 3 4 \%}$ \\
\hline Aquarius Platinum Ltd & Plat. & 840481 & 249322 & $\mathbf{3 0 \%}$ \\
\hline Randgold \& Exploration Company Ltd & Gold & 9906 & 0 & $\mathbf{0 \%}$ \\
\hline Harmony Gold Mining Company Ltd & Gold & 1451072 & 634351 & $\mathbf{4 4 \%}$ \\
\hline Northam Platinum Ltd & Plat. & 978508 & 867466 & $\mathbf{8 9 \%}$ \\
\hline Lonmin Plc & Plat. & 795811 & 2011243 & $\mathbf{2 5 3 \%}$ \\
\hline Petmin Ltd & Iron & 568745 & 314746 & $\mathbf{5 5 \%}$ \\
\hline
\end{tabular}

